

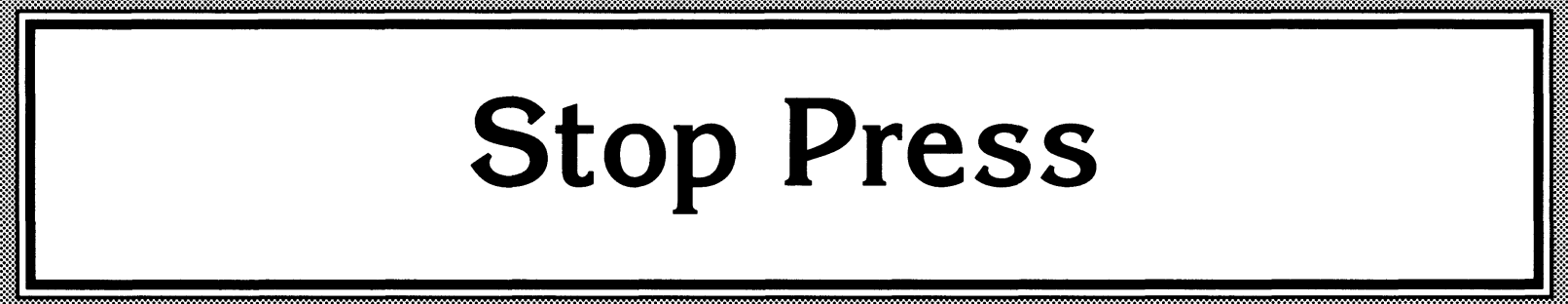




\section{About this book}

STOP PRESS is a valuable photocopiable resource pack using the newspaper to stimulate students' interest in reading and to develop all aspects of communication skills, and greater social awareness. Real reading is the best way to improve reading, understanding and communication and this pack guides tutors and lecturers to use it to the full.

Newspapers are a huge inexhaustible and cheaply available source of highly contemporary easy-to-digest reading; in STOP PRESS Jan Hulley and David Mastin show how to exploit them as stimulus material.

Presenting current types of newspaper articles and worksheets the authors provide models for classes around vital contemporary issues: crime, life styles, personal money, consumer and social issues, never losing sight of the main focus on reading and communication skills. The package is highly flexible as tutors are encouraged to add relevant articles of appropriate difficulty from today's local and national papers - the papers their own students read.

STOP PRESS begins with simple materials, but as tutor and learner progress, so they move into material about how the papers themselves work and are put together. The pack aims to stimulate the desire to read and understand an adult text, and in the process to help develop more socially aware citizens.

Photocopying restrictions are waived for bona fide lecturers, teachers and tutors to reproduce multiple copies as teaching material within their institutions.

Jan Hulley is a Lecturer and Neighbourhood/Community Co-ordinator for Basic Education at Loxley College, Sheffield. She is committed to researching and developing access to education for those who have been unable to participate fully and has researched basic skills and the Black Literacy Campaign in New York. She has been responsible for initiatives in dyslexic tuition for adults, in open learning for basic education students, and in community integration for special needs students.

David Mastin is Production Editor of The Star, Sheffield, a multi-edition regional evening newspaper. He has worked as a Crime Reporter, and later as News Editor and Assistant Editor on The Star. His dedication to maintaining high standards and journalistic integrity in regional newspapers has been recognised with a commendation in the Production Team of the Year category of the British Press Awards for 1988 and a 'highly commended' in the 1986 Yorkshire Press Awards. 


\title{
Stop Press
}

An enriching and rewarding use of a daily newspaper

for tutors and students

\author{
Jan Hulley \\ David Mastin
}

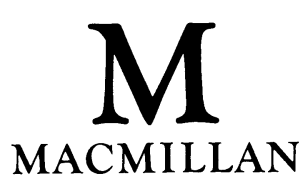


(c) Jan Hulley \& David Mastin 1989

Softcover reprint of the hardcover 1st edition 1989 978-0-333-51398-9

All rights reserved. No reproduction, copy or transmission of this publication may be made without written permission except under the terms set out below.

This publication is copyright, but teachers are free to reproduce it by any method without fee or prior permission, provided that the number of copies made does not exceed the amount required in their school For copying in any other circumstances (e.g. by an external resource centre) prior written permission must be obtained from the publishers and a fee may be payable.

Any person who does any unauthorised act in relation to this publication may be liable to criminal prosecution and civil claims for damages.

First published 1989

Published by

MACMILLAN EDUCATION LTD

Houndmills, Basingstoke, Hampshire RG21 2XS

and London

Companies and representatives

throughout the world

Designed and typeset by

Four $\mathrm{H}$

Chalgrove

Oxford

British Library Cataloguing in Publication Data

Hulley, Jan

Stop press: an enriching and rewarding use of

a daily newspaper for tutors and students.

1. Adult literacy education. Teaching aids. Newspapers

I. Title

II. Mastin, David

374.012

ISBN 978-1-349-11231-9 ISBN 978-1-349-11229-6 (eBook)

DOI 10.1007/978-1-349-11229-6

\section{Acknowledgements}

The authors and publishers wish to thank the following who have kindly given permission for the use of copyright material: Sheffield Newspapers Ltd for extracts from The Star; Solo Syndication on behalf of Mail Newspapers Plc for an extract from the Daily Mail; Today for extracts from Today.

Every effort has been made to trace all the copyright holders but if any have been inadvertently overlooked the publishers will be pleased to make the necessary arrangement at the first opportunity. 


\section{Contents}

About this book ii

Notes for tutors 1

Pictorial overview 6

\section{Unit 1}

\section{Advice and information}

\section{Tutor notes}

1 Introduction to the columns

\section{Worksheets}

2 Financial advice

101 Newspaper columns

3 The horoscope

122 Financial advice

4 Travel

143 Your stars

5 Advice and information

164 Travel

\section{Unit 2}

\section{Health and fitness}

\section{Tutor notes}

Suggested topics

1 Health and fitness

2 A guide to good eating

3 Using supermarket adverts

4 Drugs and performance

\section{Worksheets}

$30 \quad 1$ Health and fitness 39

312 A guide to good eating 42

$33 \quad 3$ Shopping adverts 47

354 Drugs and performance 51

Unit 3

\section{Crime and the law}

\section{Tutor notes}

Suggested topics

1 Introduction to crime and its effects

37

2 Crime against property

3 Crime against people

4 Introduction to the editorial pages

5 Crime and the law summary

\section{Worksheets}

$54 \quad 1$ Conmen 66

552 Tattooed raider $\quad 67$

$57 \quad$ Property and charges $\quad 68$

593 Alleged killer $\quad 70$

624 Opinion and news $\quad 74$

645 Crimes 75 


\section{Unit 4}

\section{Getting to know the news}

\section{Tutor notes}

Introduction to the newspaper

1 Treasure hunt

2 The newspaper's many purposes

3 Classifying the news

4 Recognising an important story

5 Using the entertainment section

6 Teaching vocabulary in context through a newspaper column

7 Is it features or is it news?

8 The continuing story

9 Using the cinema section to make entertainment plans

10 Writing an interview and constructing an interview format

11 Gathering information

12 Organisation of the news story

13 Summary activity for getting to know the news

Story of the week

111

113

86

98

106

\section{Worksheets}

881 Treasure hunt 116

902 The newspaper's many purposes 117

913 Classifying the news 122

934 Recognise a front-page story 123

965 Weekend activity 125

6 'Crack' 126

1007 A feature story or a news story? 128

1028 Chernobyl 132

10 Dreyfuss crosses the drugs divide $\mathbf{1 4 0}$

10811 Gathering information 142

10912 Organising the news story 144

13 Summary activity $\quad 147$

Unit 5

\section{Start up together}

Start up together

150 